\title{
LEXICON
}

\section{THE FLOUTING OF CONVERSATIONAL MAXIMS AND ITS RESULTS IN NEW GIRL SITUATIONAL COMEDY}

\author{
Zhafira Ayu Dhamastri
}

\begin{abstract}
This research aims to identify the types of conversational maxims that are flouted in New Girl situational comedy, study the implied meaning,investigate the most dominant conversational maxim that is being flouted, and identify the results of the flouting. This research took data from the script of New Girl sitcom season 1 episode 1-5. The result of the research shows that all types of conversational maxims, which are maxim of quantity, quality, relation, manner, and the combination of maxims are being flouted by the characters. There are 59 flouted utterances and the most flouted maxim in the situational comedy is the maxim of relation $(28,8 \%)$. There are 17 types of results of the flouting found: praise, disagreement, suggestion, declaration, agreement, action, enquiry, refusal, order, refusal and request, disagreement and persuasion, declaration and enquiry, suggestion and enquiry, agreement and enquiry, order and declaration, agreement and explanation, and also the combination of agreement, declaration, praise and order.
\end{abstract}

Keywords: implicature, cooperative principle, conversational maxims, flouting of conversational maxims, situational comedy, New Girl.

\section{Intisari}

Penelitian ini bertujuan untuk untuk mengidentifikasi jenis-jenis maksim konversasional yang diabaikan dalam sitkom New Girl, mempelajari arti tersiratnya, mengetahui maksim konversasional mana yang paling banyak diabaikan, serta mengidentifikasi hasil dari pengabaian maksim. Data yang diambil adalah dari komedi situasi New Girl seri pertama episode 1-5. Hasil dari studi ini menunjukkan bahwa semua jenis maksim konversasional diabaikan oleh para karakter, yaitu maksim kuantitas, maksim kualitas, maksim relasi, maksim pelaksanaan, dan kombinasi dari maksim-maksim tersebut. Ada 59 pengabaian yang ditemukan, dan maksim yang paling banyak diabaikan adalah maksim relasi, sebanyak 28,8\%. Terdapat 17 jenis respon, yaitu pujian, ketidakstujuan, saran, pernyataan, persetujuan, tindakan, pertanyaan, penolakan, perintah, penolakan dan permintaan, ketidaksetujuan dan persuasi, pernyataan dan pertanyaan, saran dan pertanyaan, persetujuan dan pertanyaan, perintah dan pernyataan, persetujuan dan penjelasan, dan yang terakhir adalah kombinasi dari persetujuan, pernyataan, pujian, dan perintah.

Kata kunci: implikatur, prinsip kerjasama, maksim-maksim konversasional, pengabaian maksim konversasional, komedi situasi, New Girl. 


\section{INTRODUCTION}

Despite the purpose of communication, that is, to express ideas, sometimes people just do not speak what they actually mean. According to Banga et al. (1), in everyday conversation, sentence meaning is not always expressed explicitly, but can also be merely implied. Therefore, the hearer often needs to make inference in order to understand the actual meaning of what is said by the speaker, and also use more meanings than is actually encoded, also known as Implicature.

Implicature is first coined by Hebert Paul Grice in 1975, to refer the implied meaning in conversations conveyed by the speakers and interpreted by the hearers. In addition to that, Griceclassified implicature in two types, conventional and conversational. Conventional implicature does not depend on any special features of the conversation. Conversationalimplicature, on the other hand, depends on features of the conversational situation or context and not just on the conventional meanings of the words used (Cohen 2-3).

The writer uses the Gricean theory on conversational implicature, which can be defined as "A different (opposite, additional, etc) pragmatic meaning of an utterance with respect to the literal meaning expressed by utterance" (qtd. in Mey 371).

Cooperative principle is expressed as an expected amount of information provided in conversation as the speaker and the listener in a conversation cooperate with each other (Grice45). Along with cooperative principle, Grice has a set of maxims, which are:

\section{a. Maxim of Quantity}

1. Make your contribution as informative as is required (for the current purposes of the exchange).

2. Do not make your contribution more informative than is required.

\section{b. Maxim of Quality}

1. Do not say what you believe to be false.

2. Do not say that for which you lack adequate evidence.

\section{c. Maxim of Relation}

Be relevant.

\section{d. Maxim of Manner}

1. Avoid unclearness of expression.

2. Avoid ambiguity.
3. Be brief.

4. Be orderly.

In communicating, sometimes the speaker does not follow those maxims, instead blatantly defies them. This situation is called flouting.According to Cutting (37), flouting is when speakers appear not to follow the maxims but expect hearers to appreciate the meaning implied.

In this research, the writer does the observation on a situational comedy, as we also know as sitcom, as situational comedy can give us a great example on how the characters breach the maxims while communicating with each other. The writer uses a sitcom entitled 'New Girl' as the object of the research. This sitcom does have a lot of examples on how people actually flout maxims. The writer uses the first season of this sitcom as the object of the research because it has many floutings of conversational maxims which can be analyzed on how they create responses from other characters or situations after they are uttered.

The objectives of the research are: to classify the type of flouting of conversational maxims in 'New Girl' situational comedy season 1 episode $1-5$, to identify the contexts and the meanings of the floutings of conversational maxims in the sitcom, to identify and classify the result of the flouting of conversational maxims in 'New Girl' situational comedy, as in the types of responses done by the characters after the speaker flouts the conversational maxims, to discover which conversational maxims in 'New Girl' season 1 episode 1-5 often flouted by the characters.

\section{THE FLOUTINGS AND THEIR RESULTS IN NEW GIRL SITUATIONAL COMEDY}

From the analysis conducted, there are 59 cases of the floutings of conversational maxims. Out of the 59 cases of the floutings, the writer found 17 cases flouting of maxim of relation, 15 cases flouting of maxim manner, 14 cases flouting of maxim of quantity, 7 cases of flouting of maxim of quality, and the last is 6 cases of combination of maxims. The table below shows the percentage of the each type of flouting found: 
Table 1 The Number of Occurrence of the Flouting of Conversational Maxims in 'New Girl' situational Comedy

\begin{tabular}{|c|l|c|c|}
\hline \multirow{2}{*}{ No } & \multirow{2}{*}{ Types of Flouting } & \multicolumn{2}{|c|}{ Frequency } \\
\cline { 3 - 4 } & & Number & Percentage \\
\hline 1 & Maxim of Quantity & 14 & 23.7 \\
\hline 2 & Maxim of Quality & 7 & 11.9 \\
\hline 3 & Maxim of Relation & 17 & 28.8 \\
\hline 4 & Maxim of Manner & 15 & 25.4 \\
\hline 5 & Combination of Maxims & 6 & 10.2 \\
\hline & Total & 59 & 100 \\
\hline
\end{tabular}

The table above shows that maxim of relation is the most flouted by the characters of 'New Girl' situational comedy with the amount of $28,8 \%$.

Table 2 The Number of Occurrence of the Flouting of Combination of Maxims in 'New Girl' situational Comedy

\begin{tabular}{|c|l|c|c|}
\hline \multirow{2}{*}{ No } & \multirow{2}{*}{$\begin{array}{c}\text { Types of Flouting of } \\
\text { Maxim of Combination }\end{array}$} & \multicolumn{2}{|c|}{ Frequency } \\
\cline { 3 - 4 } & Number & Percentage \\
\hline 1 & Quantity and Relation & 4 & 66.67 \\
\hline 2 & Quality and Manner & 1 & 16.67 \\
\hline 3 & Quantity and Manner & 1 & 16.67 \\
\hline \multicolumn{2}{r}{ Total } & 6 & 100 \\
\hline
\end{tabular}

Table 2 shows the number of occurrence of the flouting of combination of maxims, with the total occurrence of six times. The combination of maxim quantity and relation appears to be the most frequently flouted with the totaloccurrence of four times or $66.67 \%$ of the total amount. The flouting of maxim quality and manner and quantity and manner appear in the same amount, which is $16.67 \%$.

Table 3 The Types of Responses of Each Maxim

\begin{tabular}{|c|l|l|}
\hline No & Types of Flouting & \multicolumn{1}{|c|}{ Types of Results } \\
\hline 1 & Maxim of Quantity & Praise \\
& & Agreement \\
& & Disagreement \\
& Action \\
& Declaration \\
& Enquiry \\
& Declaration and Enquiry \\
& Refusal and Request \\
\hline
\end{tabular}

\begin{tabular}{|c|c|c|}
\hline No & Types of Flouting & Types of Results \\
\hline \multirow[t]{4}{*}{2} & \multirow[t]{4}{*}{ Maxim of Quality } & Suggestion \\
\hline & & Declaration \\
\hline & & Enquiry \\
\hline & & Action \\
\hline \multirow[t]{8}{*}{3} & \multirow[t]{8}{*}{ Maxim of Relation } & Declaration \\
\hline & & Action \\
\hline & & Enquiry \\
\hline & & Disagreement \\
\hline & & Suggestion \\
\hline & & Agreement \\
\hline & & Agreement and Explanation \\
\hline & & Order and Declaration \\
\hline \multirow[t]{9}{*}{4} & \multirow[t]{9}{*}{ Maxim of Manner } & Agreement \\
\hline & & Declaration \\
\hline & & Refusal \\
\hline & & Order \\
\hline & & Action \\
\hline & & Enquiry \\
\hline & & Disagreement and Persuasion \\
\hline & & Enquiry and Declaration \\
\hline & & Order and Declaration \\
\hline \multirow[t]{8}{*}{5} & Combined Maxims & \\
\hline & \multirow[t]{4}{*}{ Quantity Relation } & Declaration and Enquiry \\
\hline & & $\begin{array}{l}\text { Agreement, Declaration, } \\
\text { Congratulation and Order }\end{array}$ \\
\hline & & Enquiry \\
\hline & & Disagreement \\
\hline & \multirow[t]{2}{*}{ Quality Manner } & Enquiry and Suggestion \\
\hline & & Action \\
\hline & Quantity Manner & Agreement and Enquiry \\
\hline
\end{tabular}

Based on the table, there are 17 types of responses found: praise, disagreement, suggestion, declaration, agreement, action, enquiry, refusal, order, refusal and request, disagreement and persuasion, declaration and enquiry, suggestion and enquiry, agreement and enquiry, order and declaration, agreement and explanation, and the combination of agreement, declaration, praise and order all at once.

\subsection{Flouting of Maxim Quantity}

Below is the example of flouting of maxim quantity with the result of praise:

Context: Nick, Schmidt, Jess and Coach are at the bar where Nick works. The boys are chatting while watching Jess hook up with Peter, Benjamin's friend. Jess and Peter then walk up to them as Peter says his goodbye 
to Jess, saying 'See you tomorrow'. Jess looks happy after talking to Peter and the boys are curious about what will happen tomorrow, so Nick asks her.

(1) NICK: So what's happening tomorrow, sailor?

JESS: You know what, you guys were totally right. I talked in short sentences, I didn't sing, I laughed, I smiled, I said I needed rebound sex and it totally worked. He asked me out. Dinner, with food.Oooh oooh.

SCHMIDT: I'm so proud of you. (Hugs her)

COACH: You got it girl.

SCHMIDT: You did good.

COACH: You got it down. [Ep1Quan1]

In this conversation, Jess flouts the maxim of quantity by giving too much unimportant information regarding her and Peter, and at the same time lack of information on what will happen the next day. The maxim of quantity needs the speaker to give just enough information to the hearer. However, some of the information Jess utters is not really necessary to answer Nick's question and can actually be dismissed, thus make it the flouting of maxim of quantity. Jess can easily say 'He asked me out to dinner tomorrow' to effectively answer Nick's question, instead she only says 'He asked me out. Dinner, with food., which cannot really answer Nick's inquiry because he asks what will happen tomorrow, not what Peter said to Jess earlier that night. By saying 'He asked me out. Dinner, with food', however, implies that Peter asks her out to have dinner with him tomorrow. However, according to urbandictionary.com, dinner can also be defined as naked cuddling. The phrase 'with food' here emphasizes that Jess and Peter will have actual dinner, which is the last meal at the evening. The boys, nonetheless, understand that Jess means she is going to have actual dinner with Peter tomorrow, shown by the praises they give to Jess and even hugs her, which also makes this a flouting.

The following conversation containsthe flouting of maxim quantity where the speaker gives less information than is required, which results in refusal and request:

Context: Schmidt and Gretchen are in a wedding. Whenever they meet at a wedding, they always end up having sex after the wedding is over. Other than having sex, Gretchen always makes Schmidt do things for her. Gretchen spots Schmidt and she asks him whether he is ready for tonight and that she is going to show the newest pictures of herself in a river-rafting trip. Schmidt, who is always exasperated to do things with Gretchen, asks her how many of the photos she will show him.

(2) GRETCHEN: Are you ready for tonight? I'm gonna tie you down and show you pictures of my river rafting trip.

SCHMIDT: Oh, god, how many are there?

GRETCHEN: It's a two hour-slide show.

SCHMIDT: No! Gretchen, we can't do this anymore, okay. It's not...it's not healthy, alright, please, no more. [Ep3Quan2]

In the conversation above, Gretchen flouts the maxim of quantity by giving Schmidt too little information. The maxim of quantity requires the speaker to give not too little nor too much information. However, when Schmidt is asking how many of the photos Gretchen is going to show him, instead of giving him an exact number, she says 'It's a two-hour slide show', which implies that there are so many of her photos, as well as showing that Gretchen flouts the maxim of quantity. It shows that Gretchen does not know the exact number of her photos, neither does she know the exact number of the photos in the common length of a photo slide. Schmidt appears to know that two-hour slide show means so many photos he has to see, that then results in him refusing her invitation, saying that they cannot do this anymore and that it is not healthy for the both of them to keep doing what they do. The word 'not healthy' here also implies that Schmidt does not actually like their fornication, as Gretchen enjoys sexual intercourse which involves some bondage. This refers to Gretchen's utterance 'I'm gonna tie you down and show you the pictures of my rafting trip. Schmidt also responding by giving request as he says “....please, no more."

The following conversation contains the flouting of maxim quantity and disagreement as the result:

Context: Winston is Nick and Schmidt's old flatmate. He moved out from the flat to have a career in Latvia as a basketball player, and has just come back to the States and moved in the flat again. Jess has never met Winston before and she prepares a surprise-welcome breakfast for him while Nick is watching her. 
(3) JESS: I'm so excited to meet him...

NICK: (Walking towards her) No, Jess he's sleeping. He flew in late last night, we took him straight to the bar, took a bunch of shots, got drunk, screamed I love America. (Sits down) Now he's happily passed out. (Slurps coffee) Let's let him sleep.

JESS: Guess I'm not the new kid anymore, I'm just one of the guys. [Ep2Quan3]

In flouting the maxim of quantity, Nick is giving too much information about Winston and their activity the night before in order to stop Jess from giving Winston the surprise-welcome breakfast. The maxim of quantity requires the speaker to give just the right amount of information so as not to leave the hearer guess what he means, however, in this conversation, the whole information on what Nick and Winston do the night before is not really necessary. By saying that utterance, Nick implies that Winston is tired and the words'let's let him sleep' imply that Jess should not be bothering him right now.

This results in Jess disagreeing with Nick's warning, thinking that what Nick says is not true and she will not bother Winston as she is not the 'new kid' in the flat anymore and he is just the same as Nick and Schmidt.

\subsection{Flouting of Maxim Quality}

Below is the example on the flouting of maxim of quality with the result of suggestion:

Context: Nick, Schmidt and Jess are in the bathroom. Nick and Schmidt are talking about a party Schmidt wants to attend when Jess calls out from the shower stall, saying that there is a person there. Schmidt then asks Jess whether she has shaved her legs fronts and backs or not, and Nick seems frustrated to be living with them. Nick then says that he is going to kill himself.

\section{(1) NICK: (Quietly) Ok, I'm gonna kill myself now.}

SCHMIDT: Just call Caroline, you call her all the time when you're drunk. [Ep1Qual1]

In the conversation above, Nick flouts the maxim of quality by lying. By saying that he is going to kill himself, Nick flouts the maxim of quality as he is not actually going to kill himself, or in other words, he is lying. In this case, Nick's utterance is used as a means to show his feelings. It implies that he can barely bear his flatmates and thus he lets his frustration out by saying that he is going to kill himself. Actually, it is a common expression to show someone's frustration or when a person is so done of something. When Nick says that, certainly he does not expect Schmidt to save him or stop him from killing himself, and Schmidt knows that Nick is only exaggerating things as he chooses not to take it seriously by suggesting calling Caroline, Nick's ex-girlfriend, just like the other times when he was drunk. Usually, when Nick is drunk, he is sad or frustrated and he calls his ex-girlfriend a lot under alcohol influence. Schmidt, knowing Nick's frustration, then suggests him call Caroline to vent. In this situation, Nick is so frustrated with his flatmates, thus the suggestion.

Below is an example on the flouting of maxim of quality with the result of declaration:

Context: Cece, Schmidt, Nick and Coach are in the boys' flat, waiting for Jess getting ready for her first date after breaking up with Spencer. Cece, as Jess' longtime bestfriend, gives the boys 'the bestfriend talk'. She does not believe in the boys fully yet since Jess did not know the boys at all when she moved in there. She is rather worried that the boys will let something bad happen to Jess and that the boys will not keep her safe while living there.

(2) CECE: Listen to me you guys, Jess is by far the best person that I know, so if you guys let anything happen to her, I'm gonna come here, and crazy murder you.

SCHMIDT: I'm gonna be honest with you. I did not hear a word you just said 'cause I can kinda see your party hats right now. [Ep1Qual2]

One of the ways the flout the maxim of quality is using exaggeration. In the conversation above, Cece flouts the maxim of quality by using exaggeration and at the same time lying. Her utterance about crazymurdering the boys is an exaggeration and a lie, which at the same time implies that she will keep an eye on the boys and will not let the boys get Jess hurt. That utterance also implies that if the boys do that, she will not let them go with that, probably not murder them but definitely do something that can make them regret 
ever letting Jess get hurt. In this case, the flouting is only a way to show the seriousness, not to actually threaten the boys. This results in Schmidt declaring that he never did hear what Cece said, showing that he understands what Cece means. The utterance 'I can kinda see your party hats right now.' also implies that Schmidt himself does not believe that him and the other boys can keep Jess from getting hurt. 'Party hats' here can imply to the time when Cece 'celebrates' after she 'crazy-murders' Schmidt, Nick and Coach.

The following conversation is the example of flouting of maxim quality with the result of enquiry:

Context: Winston, Schmidt and Jess are discussing about Jess' incident where she accidentally sees Nick's penis. She whines at the boys because she feels embarrassed and afraid that Nick is going to be angry at her. Winston then brushes it off saying that it is not a big deal and that she has seen Nick's penis a million times.

(3) JESS: What am I gonna do? He's never gonna speak to me again. I'm so embarrassed.

WINSTON: It's not a big deal. I've seen Nick's stuff, like, a million times.

SCHMIDT: You have? I mean how? [Ep4Qual3]

Winston flouts the maxim of quality as he is exaggerating his statement that he has seen Nick's penis a million times. This is clearly a lie and an exaggeration since he must not have counted the exact time he has seen Nick's penis. By saying that he has seen Nick's stuff 'a million times', he implies that he has seen Nick's penis very frequently. When he says 'I've seen Nick's stuff, like, a million times.', he is not hoping that the hearers (Jess and Schmidt) will take it literally that he has seen it one million times. The expression 'a million times' is a common expression that something has been happening or done very frequently.

The flouting then results in Schmidt making enquirydirected to Winston 'You have? I mean how?' This enquiry is a means to express Schmidt'sdisbelief and curiosity about how he has seen.

\subsection{Flouting of Maxim Relation}

Below is the examples of the flouting of maxim relation with the result of agreement and explanation:
Context: Nick, Schmidt and Coach are talking with Jess about the possibility of her moving in with them. Jess really needs a place after she leaves her flat she shared with her ex-boyfriend whom she caught cheating on her. She then expresses her wish, but the boys are hesitant because she does not know her, let alone to let her live in the same house with them.

(1) JESS: You know what, I want to live here.

\section{NICK: Actually, I still have some questions. I mean, like, no offence but we barely know ya.}

JESS: Yeah, okay, yeah. So, um, full disclosure, I'm kind of emotional right now 'cause of the break-up so I'll probably be watching Dirty Dancing at least 6 or 7 times... a day. (Coach shakes his head slightly, looks and is disgusted) Um, I'm a teacher so I bring home a lot of popsicle sticks, stufflike that. Also, I like to sing to myself - a lot. (Singing) A lot... I'm tired of living with my friend. She's a model. All her friends are models. [Ep1R1]

In this conversation, Nick flouts the maxim of relation because he replies Jess' wish with something not correlated to her wish, but obvious enough to let her know his hesitation about letting her live with him. This is clashing with the idea of maxim of relation, which requires the speaker to give statement or make an utterance that is relevant with the previous utterance(s). Nick's utterance also shows that he is indirectly asking Jess to tell him and the boys more about herself. The sentence 'Actually, I still have some questions. I mean, like, no offence but we barely know ya implies that he wants to know more about Jess more without dismissing the idea of her living with them, nor accepting it. The flouting is used as a means to express his hesitance and request more politely, thus the use of implied request. This can be considered as flouting because as the result, Jess gives agreement ('Yeah, okay, yeah.) and proceeds to use explanation to give him full disclosure of herself to inform Nick. It means that Jess knows what Nick wants by saying he barely knows her.

An example of the flouting of maxim relation with action as the result is presented below:

Context: Jess is trying out clothes and shoes in her room for her date with Peter. When she tries a pair of shoes on, she falls and the loud crash makes Cece, who is in her flat talking with Nick, Coach and Schmidt, come 
up to her. Jess gets a little bit too anxious of her date because she has not been in a date with anybody other than his ex-boyfriend for a long time. She gets a little bit frustrated and says that maybe she should not go, almost giving up on the date.

(2) JESS: Maybe I just shouldn't go.

CECE: Babe, you got hurt, that doesn't mean you stop trying. Okay?

JESS: (Mumbles something and nods) [Ep1R2]

Cece flouts the maxim of relation by giving irrelevant statement to Jess, opposing the idea of maxim of relation demanding the speaker on making relevant statement. Jess here says that maybe she should not go to the date, but instead of blatantly not agreeing to that idea and says that she should go, Cece gives her encouragement to Jess, saying that even though she got hurt, she cannot stop trying that cannot really answer to Jess' idea of not going to the date. By bringing up the break up (by saying 'babe, you got hurt.'), Cece does not exactly say that Jess should go, but the next clause ('that doesn't mean you stop trying.') implies that Cece wants Jess to go to the date and try going out with another man after her bad break up. Hence, the flouting in this conversation is used as a suggestion and encouragement. This results in an action done by Jess, in which she is complying, shown by her nodding, meaning that she understands the implication of what Cece says, that is that she wants Jess to go to the date and not giving up on it yet.

Another example of flouting of maxim relation, with order and declaration as the result, is presented below:

Context: Jess has just accidentally seen Nick's penis and she laughs right after she sees it. Her friendship with Nick has become weird since. After that, Jess decides to talk about it with Nick, but she cannot bring herself to say the word 'penis' because she is too embarrassed. Jess then decides to talk about it when Nick is about to go on a date.

(3) JESS: About me seeing...(Hesitates) your peen. (with British accent): The peen what I saw. (with French accent): Bonjour, le peen.

NICK: You're blocking the door.
JESS: Okay. Cool. Have fun on your date. (laughs awkwardly) (Points at Nick's penis) Tell that guy to behave. (Talks to Nick's penis) The adventure begins. [Ep4R3]

The conversation contains flouting of maxim of relation which is uttered by Nick. Nick there is giving answering Jess by making a statement that is not relevant with Jess' utterance, making it a flouting of maxim of relation as it requires the speaker to be relevant. The utterance 'You're blocking the door'. here implies that Nick wants to go out. By saying that, he also indirectly asking Jess to move over. The utterance's implied meaning is also obvious since the situation there is Nick being all set to head out but Jess stops him to talk about their little incident. However, the statement 'You're blocking the door.' has nothing to do with Jess' utterance about Nick's penis.

This flouting then results in order and declaration. The order happens when Jess says 'Have fun on your date.' and 'Tell that guy to behave., while the declaration happens when she says 'The adventure begins.'

\subsection{Flouting of Maxim Manner}

Below is the example of the flouting of maxim of manner with the results of disagreement and persuasion:

Context: Jess and Schmidt are talking about getting Jess a rebound after breaking up with Spencer. Jess is hesitant at first, but Schmidt keeps encouraging her because he and Nick also Coach cannot take any more crying in their flat. Besides, Jess has been crying for a week and the boys are getting tired of it, so Schmidt offers a guidance on getting a rebound.

(1) SCHMIDT: You're totally ready for it, I'll take you through the whole thing. You know, I'll be like your guide!

\section{JESS: Like Gandalf through Middle-earth?}

SCHMIDT: Probably not like...okay, first of all, let's take the Lord of the Rings references, let's put 'em in a deep, dark cave, okay, where no one's gonna find them, ever. [Ep1M1] 
In the conversation above, Jess flouts the maxim of manner as she is using the 'Lord of The Ring' reference to respond to Schmidt. In the statement 'Like Gandalf through Middle-earth', Jess compares Schmidt to Gandalf and the attempt to look for a rebound to the journey in Middle-earth in the movie 'Lord of The Ring. This comparison is a pretty obscure way to explain the guidance thing she is hoping Schmidt does, as not everyone knows what or who 'Gandalf' is and the movie 'Lord of The Ring'. In this case, Jess portrays Schmidt as Gandalf who teaches her on her journey looking for a rebound after breaking up with Spencer. This portrayal then resulting on Schmidt being disagreeing on the comparison, saying 'Probably not like..., and then also persuading Jess by saying 'okay, first of all, let's take the Lord of the Rings references, let's put 'em in a deep, dark cave.'

Below is an example of flouting of maxim manner which results in agreement:

Context: Nick and Jess are at a wedding, pretending to be a couple to make Caroline, Nick's ex-girlfriend jealous as she is also attending the wedding. Nick and Jess were flirting and acting like a loved-up couple when Caroline comes over to them and attempts to make a small talk. Before Caroline has come up to them, Nick has told Jess that he wants to talk to Caroline about himself.

(2) NICK: Hey, Jess. Did you wanna go do that thing, for um...?

JESS: Yes, I did. I wanted to do it very badly... (Leaves) [Ep3M2]

Nick flouts the maxim of manner here as he makes an obscure question to Jess. The maxim of manner expects the speaker to use clear expression, avoid ambiguity and obscurity. However, in this case, Nick cannot even finish his sentence, saying 'Did you wanna go do that thing, for um...?' to Jess, only making his question vague and hard to understand. By saying that, Nick implies that Jess should go, as he has told her that he wants to talk to Caroline. He also wants to make it less obvious to Caroline as they are playing pretend as lovers. The question is a code between Jess and Nick which functions as her cue to leave. The flouting in this conversation, hence, becomes some kind of a request.

The result of this flouting is Jess appearing to agree with Nick, saying 'Yes I did. I wanted to do it very badly...'
The following conversation is the example of flouting of maxim manner which results in refusal:

Context: Jess is having trouble with Nick after seeing him naked and laughing at him. On the other hand, Schmidt is complaining because it turns out that he is the only one who has never seen Nick's penis. Since then, he has been bugging Nick asking him to show him his private part. Schmidt follows Nick to the bathroom when Nick is taking a pee, and Nick is surprised because Schmidt suddenly appears from the stall.

(3) NICK: Aah!

SCHMIDT: I'm the only one who hasn't seen it.

NICK: What?

SCHMIDT: Just the gun.

NICK: No. [Ep4M3]

In this conversation, Schmidt flouts the maxim of manner by being vague when he answers Nick's question. Maxim of manner expects the speaker to avoid obscurity. However, in this case, Schmidt is not even being clear about what he wants to see. Schmidt expects Nick to understand what he wants to see because it has been clear from the start that he is the only one who has never seen Nick's genitalia. The phrase 'Just the gun.' here means that Schmidt wants to see Nick's penis only (without the testicles). The word 'gun' is on the list of Slang of Penis and Testicles, released by Stanford.

The flouting results in Nick giving direct refusal, saying 'No.', which only means that he understands what Schmidt wants to see as well as the slang 'gun'. Below is another example of flouting of maxim manner, with the result of order:

Context: Nick and Jess' friendship becomes weird after Jess accidentally sees Nick naked. Jess then tells Cece and then gets advised to show her body to Nick as a peace offering. Jess then enters Nick's room, only covered in her towel, when Nick is out to surprise him. When Nick finally comes, it appears that he is with his co-worker he was about to have a one-night-stand with the other day. Jess then crouches and moves stealthily toward the door so that Nick and his friend will not see her, however, Nick catches her and she is so surprised she drops her towel. The next day, Jess asks Nick whether he saw everything. 
(4) NICK: Get out of my room.

JESS: Okay. Hey, um (laughs) when I was, um, leaving in a hurry, um, did you see everything?

NICK: Yup.

\section{JESS: Even my gumbo pot?}

NICK: Ugh. Gumbo pot. Get out. [Ep4M4]

In this case, Jess flouts the maxim of manner by making vague reference. The maxim of manner requires the speaker to avoid obscurity. However, when saying that reference, Jess does not expect Nick to misunderstand or even do not understand her reference at all, as the situation there already explains that Jess is about to show her body to Nick. The question 'Even my gumbo pot?' implies that she wants to make sure that Nick has already seen her genitalia. The result of this flouting is Nick being disgusted by her reference, which makes him give order, saying 'Get out.' to Jess.

\subsection{Flouting of Combination of Maxims}

\subsubsection{Flouting of Maxim Quantity and Relation}

Below is the example of the flouting of quantity and relation resulting in declaration and enquiry:

Context: Schmidt asks Jess her opinion whether or not he is sexy when Jess is about to go to school. She has prepared her properties on the lesson she is teaching and she has a lot of things in her hands. Schmidt explains on why he needs her opinion, but Jess is a little bit uncomfortable on answering his question because she needs to go already.

(1) SCHMIDT: Okay look, I'm meeting a girl for drinks tonight, and I'm probably going to bring her back here, for sex.

JESS: I have to get to school 'cause it's astronomy day and I'm dressing up like Galileo, so I have to put on my beard.

SCHMIDT: I get that, but as a lady, where in the room do I look sexiest? You know like, like where am I best on display? Here? (Sits in armchair, legs crossed holding head) Here? (Sits on arm of armchair) Or (runs over to bed) here? (lies on bed on his side). [Ep2QuanR1]
Jess flouts both the maxim of relation and quantity, as she gives too much information that is not related to the previous utterance. Jess' reaction to Schmidt shows that she wants to drop the subject, as she wants to refuse Schmidt's request. Here Jess refuses by saying 'I have to go to school 'cause it's astronomy day..., which is not relevant with the previous statement by Schmidt. However, Jess' utterance refers to the request Schmidt has said before he tells her the plan. Jess' statement that he has to go to school implies that she does not have time for whatever it is Schmidt is requesting.

The following information about the astronomy day ('...and I'm dressing up like Galileo, so I have to put on my beard.') is not really necessary to be given to Schmidt, or in other words, Jess is giving too much information, which is why she is flouting the maxim of quantity too. However, the information about having to put on her beard can also be used to emphasize that she does not have time for Schmidt, but this will not appear if she does not tell Schmidt that she is dressing up as Galileo in the first place, which is not really necessary to say.

This whole utterance then draws a reaction from Schmidt, which is a declaration that he understands ('I get that, but...). He isat the same time also dismissing the whole idea by giving enquiry about where in the room he looks the best, which is his initial intention of calling Jess there.

The following example is the flouting of maxim quantity and relation resulting in agreement, declaration, congratulation and order:

Context: Nick is at a wedding. He takes a lot of picture with Caroline, his ex-girlfriend, whom he just found out already has a boyfriend, in the wedding photobooth. After knowing that Caroline already has a boyfriend, he takes the photos they took and gets drunk. He then talks to the camera provided for the bride's and groom's friends to give their congratulations on the wedding. However, instead of congratulating the newlyweds, Nick talks about his relationship with Caroline, that then makes the Camera Man rather uncomfortable.

(2) NICK: (Holds up pictures from the photo booth) That's Caroline and that's me. Four years we were together so...it doesn't matter to me, it's just what matter is..respect. (Crying) I'm just so alone right now, man and it's a real bad situation... 


\section{CAMERA MAN: Uh, Steve and Bree.}

NICK: Steve and Bree, because that's what this is about, I agree with you, you're good at your job, man. (Turning to the cardboard cut out of Steve and Bree) I'm so happy for you, you look great, it feels a little bit like you're rubbing it in my face, you know, happiness, but let's be honest, Bree, this doesn't look great on you. (Gestures to the dress) This. That's not a great look, Bree! Congratulations, Steve, nice fedora and no open bar, Steve, don't you understand that's tacky! You're dad's rich, you're a lawyer, man. (Kicks over cardboard cut out) Yeah! That happened! [Goes over to the photo booth] The photo booth is a liar, fyi. (Opens curtain) Oh, hey ladies, you guys wanna see a grown man cry? No? Then get out! I think I saw a single doctor looking at you. (To one of the women) This is gonna take a while, Orange. [Ep3QuanR2]

The Camera Man in this conversation flouts maxim of quantity and relation, as he is giving less information than is required and at the same time irrelevant to the previous utterance. Firstly, the maxim of quantity requires the speaker to give neither too little nor too much information. However, the Camera Man flouts it when he says 'Uh, Steve and Bree., leaving the hearer to have to guess what he actually means.

Secondly, the maxim of relation here is flouted because the Camera Man's utterance is not really relevant to the previous utterance. Nick here is talking about his ended relationship with Caroline, but, instead of giving his comment or saying something about it, the Camera Man mentions 'Steve and Bree', which is totally not related to Nick's story about his relationship with Caroline.

Here, the Camera Man implies that Nick needs to stop and give his congratulation to the newlyweds or his comment on the wedding instead. Only by mentioning their names, the Camera Man hopes that Nick will know his intention because it has been known what the camera is there for. This results in Nick giving agreement that he should be talking about Steve and Bree, declaring that he is happy for them and that he hates the fedora, congratulating them on the wedding, and ordering people to stop looking at him. Nick's reaction shows his understanding of the implied information the Camera Man gives, which makes the Camera Man's utterance a flouting.

\subsubsection{Flouting of Maxim Quality and Manner}

Below is the example of flouting of maxim quality and manner which results in enquiry and suggestion:

Context: Jess is at the bar, chatting with Nick who is bartending. They talk about Nick's ex-girlfriend, Caroline, who dumped Nick and actually has a bad ending with him. She tries to make Nick open up with her and asks him what happened between Nick and Caroline when they broke up.

(1) JESS: Do you know why she dumped you? I mean she must've hurt you pretty bad..

NICK: No, no, it made no difference to me, I just wanted to set her trash cans on fire.

JESS: So are you always just like wondering, like, what was it, was there something I could've done differently? Do you know what happens to people who keep it all inside? They get old, and they get sad and they get weird and then you're the old man yelling at the kids who are running across your yard and you're telling them 'Don't run across my yard, my life's full of regret'. You know, you can't just pretend like it didn't happen. [Ep1QualM1]

Here, the flouting of maxim quality and manner happen because Nick lies to Jess and at the same time being vague about his feelings to Caroline. Firstly, he says that the break up makes no difference to him, implying that Jess' statement about him being hurt by the break up is wrong, but then he says that he wants to actually set her trash cans on fire, implying that he is actually mad at Caroline. Here, Nick gives two different ideas on his feelings toward Caroline, which makes his statement about the break up making no difference to him a lie as he wants to set her trash cans on fire. At the same time, the utterance is also so vague because of the two different ideas Nick is proposing here, which is a proof that he is flouting the maxim of manner.

This vague answer shows how Nick actually does not know what he is feeling either. This can be considered as flouting because Jess, however, understands that Nick is confused and bottling it up inside, shown by her enquiring about his feelings and giving suggestion ('You know, you can't just pretend like it didn't happen'). 


\subsubsection{Flouting of Maxim Quantity and Manner}

Below is the flouting of maxim quantity and manner resulting in agreement and enquiry:

Context: Nick and Jess are in a drugstore, buying some daily necessities together. Jess is nervous and selfaware because Cece, who is crashing in theirs after a fight with her boyfriend, just told her that Nick has a special feeling for her. However, Nick does not know this. Nick then asks Jess how long Cece will be staying with them.

(1) NICK: Well, how long is she staying?

JESS: Oh, not long. I know she can be tough to deal with. Sometimes she just calls me up and she's like, "Bitch, I love you." And then she just hangs up. No other information. Weird. But I don't know, I kind of like it when she calls me "bitch." It makes me feel like Janis Joplin.

NICK: Fine, but does she have to stay with us? [Ep5QuanM1]

In the conversation above, Jess flouts the maxim of quantity and manner as she gives too much information and being obscure on answering Nick's question. Jess' utterance cannot answer Nick's question with just enough information because 'Oh, not long.' does not provide exact days or weeks on how long Cece will be staying at theirs. This at also makes her answer vague enough for Nick not to know how long she will be at theirs.

The following information about how Cece can be tough to deal with and Jess' experience with Cece is just not needed in answering Nick's question, making this extra information that can actually be disregarded as it also does not provide the exact number of days on how long Cece will be with them.

Jess' utterance implies that she might not know how long Cece will be staying, thus the vague answer, and the other information is a means to drop the subject, at the same time showing that she can understand that Cece is sometimes a little bit hard to handle. The utterance 'Oh, not long.' can also be a means to placate Nick. It results in Nick understanding Jess' utterance, shown by him giving agreement by saying 'Fine.... This understanding, even though followed by a complaint, is another proof that Jess' utterance is a flouting.

\section{CONCLUSION}

There were 59 flouting of conversational maxims in the first five episodes of New Girl situational comedy season 1; 17 cases of flouting of maxim relation, 15 cases of flouting of maxim manner, 14 cases of flouting of maxim quantity, 7 cases of flouting of maxim quality and the least was the flouting of combination of maxims which appears 6 times. The writer also found that the responses from the hearer could vary. There are 17 types of responses the writer found, which are praise, disagreement, suggestion, declaration, agreement, action, enquiry, refusal, order, refusal and request, disagreement and persuasion, declaration and enquiry, suggestion and enquiry, agreement and enquiry, order and declaration, agreement and explanation, and also the combination of agreement, declaration, praise and order. Even though the responses varied, the hearer understood the flouting uttered by the speaker.

\section{REFERENCES}

Banga et al. Some Implicatures Reveal Semantic Differences. 2009. PDF File. <www.let.rug.nl/ hendriks/papers/bangaetal09.pdf>

Cutting, Joan. Pragmatics and Discourse. Florence, KY, USA: Routledge, 2002. Print.

Grice, Paul Herbert. Logic and Conversation. Berkeley: University of California, 1975. PDF File.<http:// terpconnect.umd.edu/ israel/Grice75.pdf>

Mey, Jacob. Pragmatics: An Introduction. Malden: Blackwell Publishing, 2001. PDF File.<http:// www.mohamedrabeea.com/books/book1_2742. pdf>

Yule, George. Pragmatics. Oxford: Oxford University Press, 1996. PDF File.<https://abudire.files. wordpress.com/2012/01/pragmatics_oxford_ introductions_to_language_study_2.pdf >

TS: A typescript or a work prepared by machine.

\section{Internet sources:}

http://cucirca.eu/watch-new-girl-online-free-fullepisodes/\#season1. Web. October 1st 2015.

http://www.imdb.com/title/tt1826940/. Web. October 10th 2015. 
https://www.msu.edu/ jdowell/monro.html. Web.

October, 10th 2015.

newgirl.wikia.com. Web D.O.D October 1st 2015. http://www.springfieldspringfield.co.uk/episode_ scripts.php?tv-show=new-girl. Web. D.O.D October 1st 2015.

https://en.wikipedia.org/wiki/New_Girl. Web.

October 10th 2015. http://web.stanford.edu/ eckert/PDF/ PenisTesticlesSlang.pdf. Web. D.O.DFebruary 17th 2016.

https://faculty.washington.edu/smcohen/453/ GriceLogicDisplay.pdf. Web. D.O.DFebruary $1^{\text {8th }}$ 2016. 